\title{
SUMBER MIMPI DALAM PERSPEKTIF HADIS
}

\author{
M. Yusuf Assagaf \\ M. Galib \\ M. Abduh Wahid \\ yusufsegaf2@gmail.com \\ Mahasiswa Pascasarjana UIN Alauddn Konsentrasi Hadis
}

Abstrak: Tulisan ini mengelaborasi tentang sumber mimpi dalam perspektif hadis Nabi. Metode yang digunakan dalam pengumpulan hadis adalah metode takhrij yang meng-analisis (tah/ili) kandungan hadis dengan menggunakan pendekatan Ilmu Hadis dan Ilmu Psikolog.

Hasil penelitian ini menunjukkan mimpi adalah sebuah peristiwa yang terlihat ketika seseorang tertidur, di mana mimpi itu terkadang mengandung kebenaran dan terkadang pula hanya sekedar bunga tidur yang tidak terdapat unsur kebenaran di dalamnya. Sementara hadis alru'yā śaläsah terdapat 13 riwayat melalui 2 sahabat dari 7 Mukharij. Sanad dan matan hadis yang diteliti berkualitas sahịh. Sanadnya dinilai sahịh karena periwayatannya bersambung, periwayatnya 'ádil dan ḍābit, serta tidak ditemukan syäż dan 'illah pada matannya. Meskipun matan

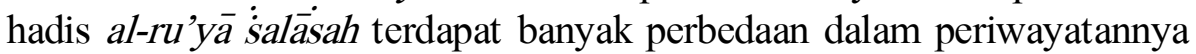
karena mengalami penambahan (ziyādah), pengurangan (nuqsănn), pemutar balikkan lafal (inqilāb), perubahan (tagyir), dan sisipan (idräj), akan tetapi semua itu tidak merusak makna hadis sehingga terhindar dari 'illah. Matan hadis al-ru'yā śaläsah juga selaras dengan al-Qur'an, hadis sahịh, sejarah dan logika sehingga terhindar dari syäż.

Secara teks mimpi terdapat 3 macam: yakni 1. Kabar gembira dari Allah, 2. Omongan diri sendiri dan 3. Kekhawatiran dari syaitan. Namun jika dilihat dari segi kandungan hadis al-ru'yā $\dot{s} a l \bar{a} \dot{s} a h$, terdapat 3 kandungan yaitu 1. Sumber datangnya mimpi, 2. Materi mimpi dan 3. Adab-adab ketika bermimpi.

Tulisan ini diharapkan menambah pemahaman kepada masyarakat bahwa mimpi bukanlah semata-mata sekedar bungan tidur, melainkan mimpi itu terkadang mengandung unsur kebenaran yang dapat berupa kabar gembira, petunjuk, peringatan dan sebagainya yang berasal dari Allah, dan terkadang pula mimpi itu hanyalah gangguan dari syaitan yang bertujuan untuk membuat seseorang khawatir, berseduh hati, takut bahkan sampai membuatnya sakit.

\section{Kata Kunci: Mimpi, al-Ru'yah, al-Hulm}

\section{PENDAHULUAN}

Hadis Nabi saw. di samping sebagai sumber hukum, juga merupakan sumber ajaran bagi umat Islam yang memberikan pengajaran mulai dari persoalan yang besar hingga persoalan kecil, bahkan persoalan yang dianggap sepele oleh umat Islam itu sendiri. Di antara persoalan kecil yang diajarkan oleh Nabi saw adalah mimpi.

Mimpi adalah suatu peristiwa yang sering dialami oleh manusia ketika sedang tertidur. Pada hakikatnya mimpi berada pada alam bawahsadar manusia yang tidak 
terikat oleh ruang dan waktu sehingga melalui mimpi, manusia dapat melihat, merasakan serta melakukan sesuatu dan yang tidak mungkin bahkan mustahil terjadi saat berada pada alam sadarnya.

Berdasarkan sejarah yang diabadikan dalam al-Qur'an, ternyata mimpi juga dialami oleh nabi-nabi. Salah satu mimpi yang diabadikan dalam al-Qur'an adalah mimpi nabi Yusuf as. Allah swt. berfirman dalam QS. Yusuf : 4.

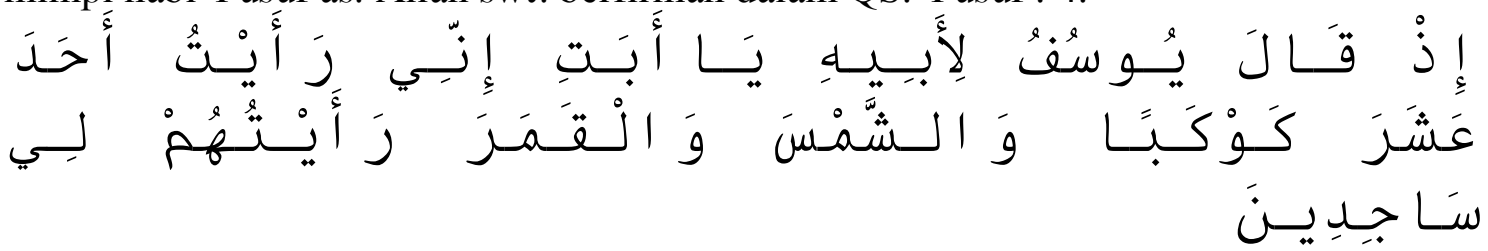

Terjemahnya;

(Ingatlah), ketika Yusuf berkata kepada ayahnya: "Wahai ayahku sungguh aku

(bermimpi) melihat sebelas bintang, matahari dan bulan; kulihat semuanya sujud kepadaku."1

Pada ayat tersebut diinformasikan bahwa nabi Yusuf as. dalam mimpinya melihat 11 bintang, matahari serta bulan telah bersujud kepadanya. Menurut logika manusia, kajadian tersebut sangat sulit untuk diterima oleh akal karena baik bintang, matahari, maupun bulan tidak pernah disaksikan oleh manusia bersujud di alam sadar. Tetapi hal tersebut dapat diterima atas dasar iman oleh karena kemulian yang dimiliki oleh Nabi Yusuf as. Namun, al-Ṭabariy dalam tafsirnya mengatakan bahwa yang dimaksud 11 bintang pada ayat tersebut adalah 11 orang saudaranya, sementara matahari dan bulan adalah ayahnya. ${ }^{2}$

Nabi Muhammad saw. melalui hadis-hadisnya juga menyampaikan bahwa dirinya pernah mengalami mimpi, sebagaiamana yang diriwayatkan oleh imam alBukhāri dari jalur periwayatan 'Aisyah yang menceritakan bahwa Rasulullah pernah melihat dirinya dalam mimpi. Adapun lafal hadis tersebut adalah ;

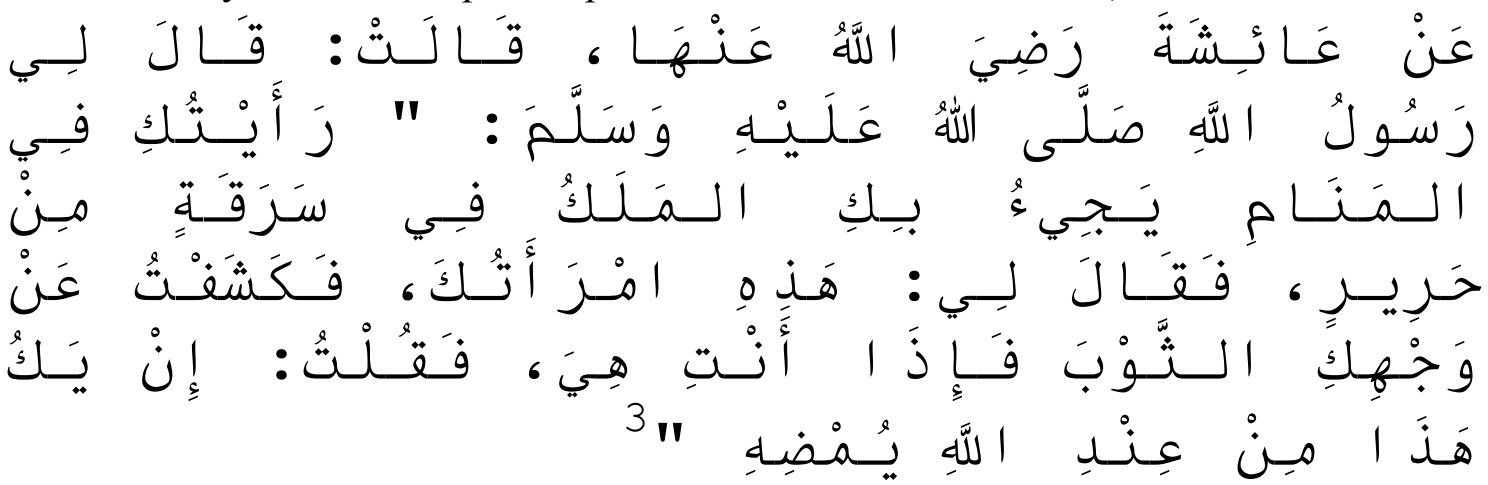

Artinya;

Dari ' $\bar{A}$ 'isyah radiallahu 'anhā, ia berkata; Rasulullah saw. pernah bersabda kepadaku: "Aku melihatmu di alam mimpiku. Kamu dibawa oleh Malaikat dengan

\footnotetext{
${ }^{1}$ Departemen Agama RI, Al-Qur'an dan Terjemahnya, (Cet., I, PT Tiga Serangkai Pustaka Mandiri, 1430 H/2009 M), h. 235.

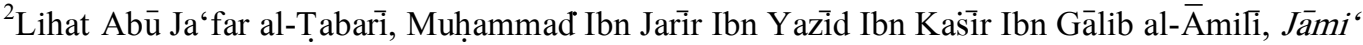
al-Bayān fì Ta'wìl al-Qur'ān, Juz XV, (Cet. I; t.t: Mu'assasah al-Risālah, 1420 H/2000 M), h. 556.

${ }^{3}$ Al-Bukhārì Muhammad Ibn Ismā'il Abū 'Abdillah al-Ju'fì, Al-Jāmi' al-Ṣaḥiḥ, Juz VII, (Cet. I; t.t: Dār Tūuq al-Najāh, 1422 H), h. 14.
} 
bertutupkan kain sutera, lalu Malaikat itu pun berkata padaku, 'Ini adalah isterimu.' Maka aku pun menyingkap kain yang menutupi wajahmu, dan ternyata wanita itu adalah kamu. Maka aku pun berkata, 'Kalau hal ini datangnya dari Allah, maka Allah pasti akan menjadikan kenyataan."'

Pada dasarnya mimpi para nabi dan rasul merupakan wahyu dan pasti memiliki makna, sementara mimpi manusia biasa (selain nabi dan rasul) kemungkinan benar dan berasal dari Allah swt dan adakalanya hanya sekedar bunga tidur ataupun gangguan dari setan. Sebagaimana hadis yang diriwayatkan oleh Imam al-Dārimī dari Abu Hurairah ra.

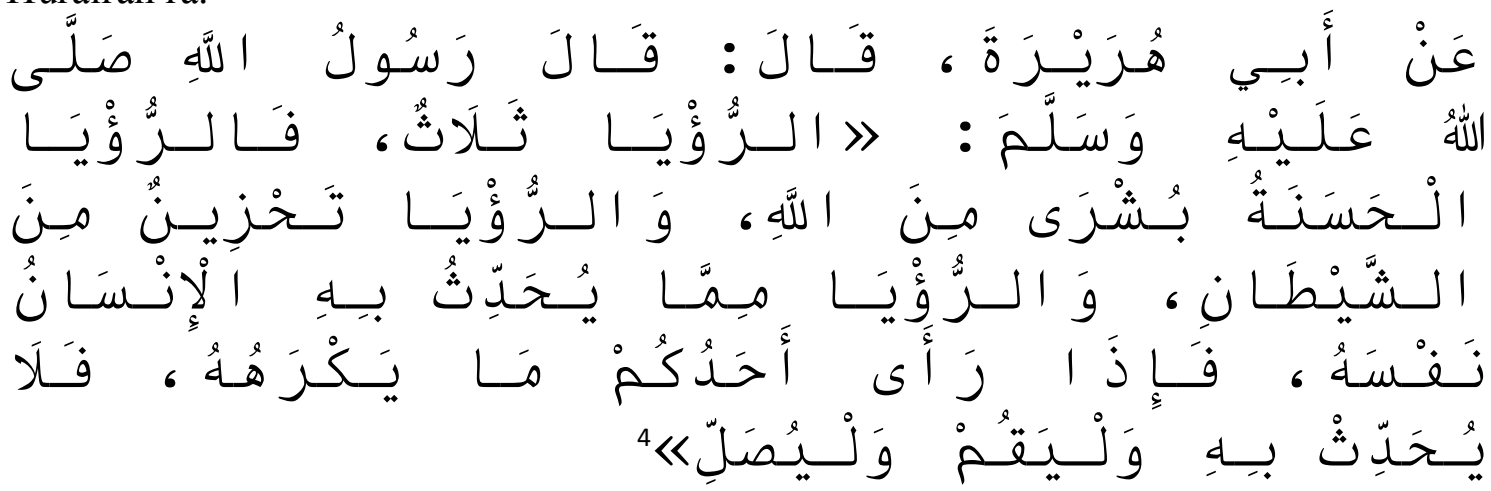

Artinya;

Dari Abū Hurairah ia berkata; Rasulullah saw. bersabda: "Mimpi ada tiga, yaitu; mimpi baik yang merupakan kabar gembira dari Allah, dan mimpi menyedihkan yang datangnya dari Syetan, serta mimpi yang terjadi karena ilusi seseorang. Apabila salah seorang dari kalian bermimpi sesuatu yang tidak ia sukai, hendaknya ia tidak menceritakannya dan hendaknya ia berdiri lalu mengerjakan shalat."

Hadis di atas menjelaskan bahwa mimpi itu ada 3 macam yaitu mimpi yang baik berupa kabar gembira dari Allah, mimpi buruk berasal dari setan, dan mimpi yang datang dari diri sendiri. Selain itu, hadis di atas juga menjelaskan tentang larangan bagi umat Islam menceritakan mimpi yang tidak disukainya.

Berdasarkan uraian-uraian di atas, maka peneliti tertarik untuk mengkaji hadis tentang 3 macam mimpi. Hal ini dilakukan agar umat Islam dapat memahami mimpi yang dialaminya.

\section{KAJIAN TEORITIK}

\section{A. Definisi Mimpi}

Terdapat ragam pendapat mengenai defenisi mimpi dikalangan ulama, ilmuan dan aliran teologi. Oleh karena itu, untuk memahami definisi mimpi peneliti akan memaparkan ragam pendapat dari kalangan ulama, aliran teologi dan aliran keilmuan tersebut.

1. Mimpi menurut ulama

a. Menurut Ibn Qayyim al-Jauzi, mimpi adalah perumpamaan yang dibuat oleh malaikat yang Allah tugaskan kepada mereka untuk mengurusi mimpi agar orang

${ }^{4}$ Abū Muhammad bin 'Abdillah bin 'Abd al-Raḥman bin al-Faḍl bin Bahrām bin 'Abd al-Ṣamad al-Dārimī, Musnad al-Dārimī, Juz II, (Cet, I; Al-Mamlakah al-`Arabiyyah al-Su'ūdiyyah; Dār alMuganni li al-Nasyr wa al-Tauzi', 1412 H/2000 M), h. 1361. 
yang melihatnya dapat mengambil dalil (memahami) permisalan tersebut dengan yang serupa. ${ }^{5}$

b. Menurut Ibn Khaldūn, mimpi adalah sebuah pertanda jiwa yang berbicara pada zat ruhaninya sekilas dari gambaran-gambaran kejadian. ${ }^{6}$

c. Menurut Sālih Qubbah, mimpi itu benar, apa yang dilihat oleh orang yang tidur di dalam tidurnya adalah benar, sebagaimana yang dilihat oleh kedua matanya pada saat terjaga. Maka ketika seseorang melihat dirinya di Afrika di dalam tidurnya sementara dia berada di Baghdad, maka sesungguhnya Allah menempatkannya di Afriaka pada saat itu. ${ }^{7}$

d. Menurut M. Quraish Syihab bahwa mimpi merupakan sebuah peristiwa yang tidak terikat oleh ruang dan waktu. ${ }^{8}$

Berdasarkan perbedaan pandangan ulama perihal mimpi, peneliti dapat menarik sebuah kesimpulan yang dapat mempertemukan antar pendapat tersebut, bahwa mimpi adalah sebuah peristiwa yang tidak terikat oleh ruang dan waktu, dimana mimpi tersebut adalah sebuah kebenaran yang diperlihatkan oleh malaikat kepada ruh manusia melalui perumpamaan-perumpamaan agar manusia mengambil pelajaran dari perumpamaan tersebut.

2. Mimpi menurut ilmuan

a. Menurut ulama filsafat, sesungguhnya perasaan kuat pada diri manusialah yang mengendalikan panca-panca indra yang zāhir. Apabila perasaan kuat itu memperoleh gambaran luar dari panca-panca indra yang zăhir maka ia akan meneruskannya kepada kekuatan khayalan yang di antara fungsinya menyusung gambar. Kemudian ketika gambar-gambar itu telah tercetak pada perasaan kuat maka ia akan menjadi penampakan yang sesuai dengan gambar-gambar luar, sesungguhnya gambar-gambar luar itu tidak akan menjadi sebuah pemandangan karena adanya gambar luar, akan tetapi oleh karena wujudnya mengikut pada perasaan kuat. ${ }^{9}$

b. Menurut ahli hadis, mimpi benar itu benar adanya dan terkadang pula sebagian dari mimpi yang kacau atau tidak jelas. ${ }^{10}$

c. Menurut tokoh psikologi klinis Sigmund Freud mimpi adalah penghubung antara kondisi sadar dan tidak sadar. Mimpi bisa dikatakan sebagai kunci ketidaksadaran, mimpi melambangkan hasrat ketidaksadaran. Mimpi merupakan penggambaran

${ }^{5}$ Lihat Ibn Qayyim al-Jauzī, Muhammad Ibn Abī Bakr Ibn Ayyūb Ibn Sa'ad, Syāms al-Dīn,

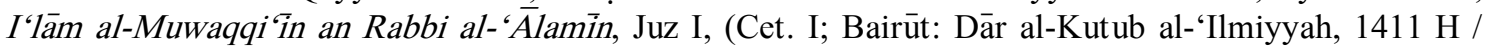
1991 M), h. 149.

${ }^{6}$ Lihat Ibn Khaldūn, 'Abd al-Raḥman Ibn Muhammaad Ibn Muhammad, Dīwān al-Mubtada' wa al-Khabr fì Tärīkh al- 'Arab wa al-Barbar, Juz I, ( Cet. II; Bairūt: Dār al-Fikr, 1408 H/1988 M), h. 128.

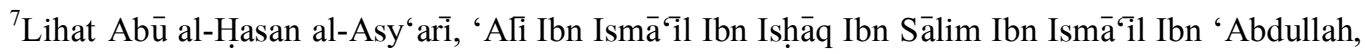
Maqālāt al-Islāmiyyīn wa Ikhtilāf al-Muṣallìn, (Cet. II; Madinah: Dār Farāniz Syitāyiz, 1400 H/1980 M), h. 434 .

${ }^{8}$ M. Quraish Shihab, Dia Dimana-Mana(Cet. IV; t.t.: Lentera Hati, 1427 H/2006 M), h. 119.

${ }^{9}$ Lihat Sahl Ibn Rifa'‘ Ibn Suhail al-'Utaibi, al-Ru'yā 'Inda Ahl al-Sunnah wa al-Jamā'ah wa alMukhālifïn, (Cet. I; t.t.: Dār Kunūz Isybiliyyah li al-Nasyr wa al-Tauzī‘, 1430 H/2009 M) h. 52.

${ }^{10}$ Lihat Abū al-Ḥasan al-Asy‘arì, Maqālāt al-Islāmiyyīn wa Ikhtilāif al-Muṣallìn, h. 434. 
dari hal-hal yang tidak bisa dilakukan di kehidupan sebenarnya, dan mimpi juga bisa menjelaskan pemecahan masalah.

Berdasarkan pendapat-pendapat di atas, peneliti memperoleh kesimpulan bahwa mimpi merupakan sebuah pertanda ketidaksadaran manusia ketika tertidur, sementara gambaran-gambaran yang terlihat dalam mimpi adalah hasil yang diterima oleh perasaan kuat dari penangkapan panca indra yang zăhir, kemudian perasaan kuat tersebut akan mengirimkan gambar-gambar tersebut kepada kekuatan khayalan yang di antara fungsinya ialah sebagai penyusun gambar, ketika gambar-gambar tersebut telah tercetak, ia akan menjadi sebuah gambaran yang serupa dengan gambaran luar, jika gambar yang dihasilkan baik maka itu akan benar-benar terjadi di alam sadar dan terkadang pula gambar kacau yang dihasilkan dapat terjadi di alam sadar.

3. Mimpi menurut aliran teologi

a. Menurut ahl al-haq al-sunnah wa al-jama'ah, mereka tidak menganggap bahwa hadis Nabi saw. telah menjelaskan mimpi tersebut dengan sejalas-jelasnya. Mimpi itu ada 3 macam; 1. Mimpi yang benar dari Allah dan hanya Allah yang mengetahui bentuknya, 2. Mimpi tertolak adalah mimpi yang tidak jelas dari gangguan, kekhawatiran dan penyerupaan setan kepada anak cucu adam, 3. Mimpi yang berasal dari seseorang pada waktu terjaganya lalu ia melihatnya dalam tidur. $^{11}$

b. Menurut mayoritas ulama mu'tazilah berpendapat bahwa apa yang dilihat oleh manusia di dalam tidurnya adalah khayalan-khayalan yang tertolak, tidak ada kebenaran di dalamnya dan tidak menunjukkan terhadap sesuatu apapun. ${ }^{12}$

Aliran ahl al-haq, ahl al-sunnah wa al-jama'ah tidak menganggap bahwa hadis Nabi saw. tentang 3 macam mimpi telah menjelaskan persoalan mimpi dengan sejelasjelasnya, sementara aliran mu'tazilah menganggap bahwa mimpi hanyalah khayalan kosong yang tidak menghasilkan apapun.

Berdasarkan penjelasan-penjelasan para ulama yang beragam mengenai defenisi mimpi, peneliti memahami bahwa mimpi adalah suatu peristiwa yang dialami oleh manusia ketika sedang tertidur. Pada hakikatnya mimpi berada pada alam bawahsadar manusia yang mana dalam kejadiannya tidak terikat oleh ruang dan waktu sehingga melalui mimpi manusia dapat melihat, merasakan serta melakukan sesuatu yang tidak bisa dilakukan ketika berada dalam keadaan sadarnya. Tetapi di sisi lain,melalui mimpi terkadang manusia memperoleh informasi tentang perkara-perkara yang akan ia hadapi kedepannya, dalam bahasa agama hal tersebut disebut sebagai petunjuk atau bimbingan dari Allah.

Melalui mimpi pula, terkadang manusia melihat berbagai macam kejadian sebagai simbol untuk menyelesaikan persoalan yang sedang dihadapi. Selain itu, terkadang pula manusia melihat kejadian yang kacau dalam mimpinya hingga membuatnya khawatir. Pada umumnya mimpi yang kacau hanyalah gangguan dari setan. Namun, adakalanya mimpi yang kacau juga merupakan sebuah pertanda akan terjadinya sesuatu di waktu yang akan datang. Salah satu dalil Nās yang menjadi landasannya adalah ayat yang terdapat pada QS Yusuf/12: 43, sebagai berikut ;

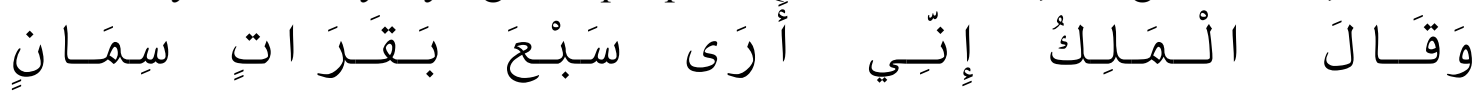

\footnotetext{
${ }^{11}$ Lihat Sahl Ibn Rifa'‘ al-'Utaibi, al-Ru'yā 'Inda Ahl al-Sunnah wa al-Jamā'ah. h. 57.

${ }^{12}$ Lihat Sahl Ibn Rifa‘‘ al-'Utaibì, al-Ru'yā 'Inda Ahl al-Sunnah wa al-Jamā'ah. h. 47.
} 


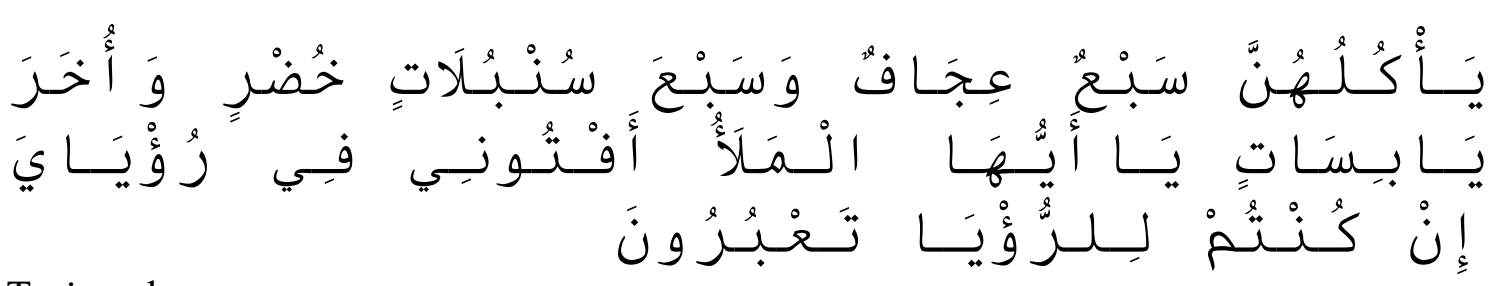

Terjemahnya ;

Dan raja berkata (kepada para pemuka kaumnya), sesungguhnya aku bermimpi melihat tujuh ekor sapi betina yang gemuk dimakan oleh tujuh ekor sapi betina yang kurus, tujuh tangkai (gandum) yang hijau dan (tujuh tangkai) lainnya yang kering. Wahai orang yang terkemuka terangkanlah kepadaku tentang takwil mimpiku itu jika kamu dapat menakwilkan mimpi. ${ }^{13}$

Al-Bagawī dalam kitabnya Ma'ālim al-Tanzīl fi al-Tafsì al-Qur'ān menerangkan bahwa ayat di atas merupakan penyebab dikeluarkannya Nabi Yusuf a.s. dari penjara, dimana seorang raja Mesir yang berkuasa pada masanya, telah bermimpi melihat 7 sapi gemuk dimakan oleh sapi kurus, dan 7 tumbuhan yang hijau lagi subur sementara yang lainnya kering. Lantas sang raja memanggil seluruh ahli takwilnya untuk menakwilkan mimpi tersebut, akan tetapi tak satupun dari mereka yang dapat menakwilnya. Maka salah seorang di antara mereka berkata bahwa di dalam penjara ada seorang laki-laki yang sangat mahir menakwilkan mimpi yang bernama Yusuf. Raja pun memerintahkan untuk memanggil Nabi Yusus a.s.

Nabi Yusuf pun menakwil mimpi sang raja dengan mengatakan bahwa maksud dari 7 ekor sapi gemuk dan tumbuhan yang subur itu adalah pertanda akan terjadi kesuburan di daerah tersebut selama 7 musim, sementara 7 ekor sapi kurus dan tanah kering adalah pertanda akan terjadinya musim paceklik selama 7 musim. ${ }^{14}$

Memahami dan memaknai sebuah kejadian baik ataupun buruk yang terlihat dalam mimpi bukanlah hal mudah, karena hanya orang-orang yang diberikan pengetahuan khusus oleh Allah swt. yang dapat menjelaskan peristiwa dalam mimpi. Sebagaimana firman Allah dalam QS Yusuf/12:6;
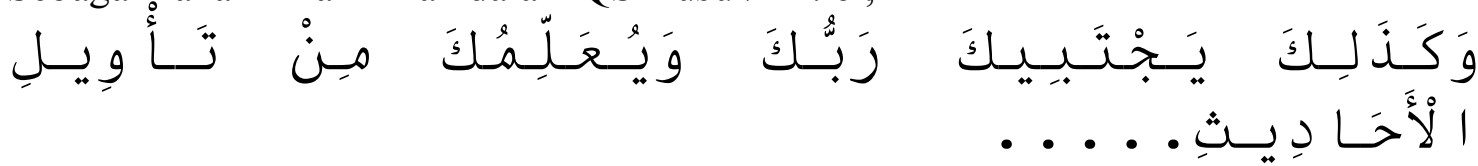

Terjemahnya ;

Dan demikianlah, Tuhanmu memilih engkau (untuk menjadi Nabi) dan mengajarkanmu sebagian dari takwil mimpi. ${ }^{15}$

Ayat di atas pada dasarnya menyinggung tentang bagaimana Allah telah memilih Yusuf a.s. sebagai Nabi, beserta keistimewaan untuknya yang mampu menakwil mimpi dan diajarkan oleh Allah sendiri. Hal ini mengindikasikan bahwa persoalan takwil mimpi adalah keistimewaan yang diberikan oleh Allah kepada orangorang terkhusus atau terpilih dan diperoleh melalui pengajaran langsung dari Allah.

\section{B. Term-term Mimpi}

${ }^{13}$ Departemen Agama RI, Al-Qur'an dan Terjemahnya, h. 240.

${ }^{14}$ Lihat al-Bagawi, al-Ḥusain Ibn Mas'ūd Ibn Muhammad Ibn al-Firā'̄ì al-Syāfi' $\bar{i}$ Abū Muhammad, Ma'ālim al-Tanzīl fi al-Tafsìr al-Qur'ān, Juz IV, (Cet. IV; t.t., Dār Tayyibah li al-Nasy wa al-Tawzi‘ 1417 H / 1997 M). h. 246.

${ }^{15}$ Departemen Agama RI, Al-Qur'an dan Terjemahnya, h. 236. 
Hadis-hadis yang berasal dari Nabi saw. sangat banyak yang menyinggung perihal tentang mimpi, salah satunya ialah hadis yang diriwayatkan oleh al-Imām alBukhāri dalam kitabnya al-Jāmi ‘ al-Musnad al-Ṣaḥih dari sahabat Abì Qatādah sebagai berikut ;

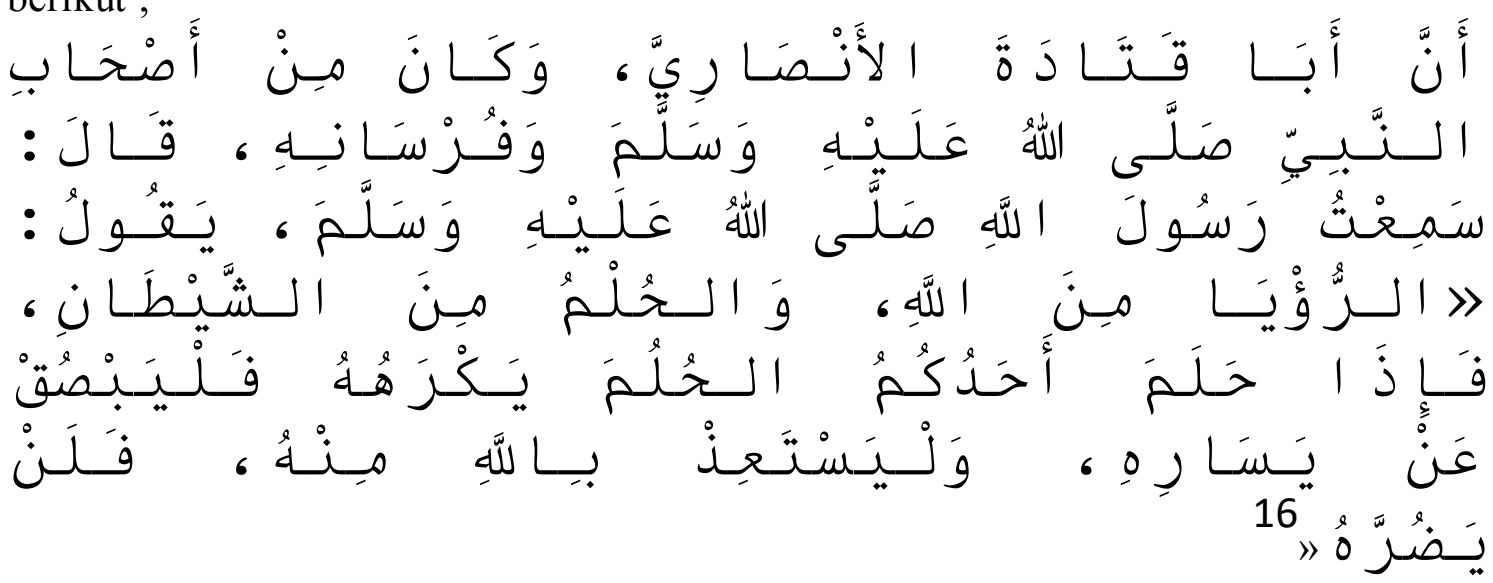

Artinya;

Dari Abū Salamah, bahwasanya Qatādah al-Anșāri dan dia termasuk dari kalangan sahabat Nabi saw. dan pejuang penunggang kudanya, mengatakan; aku mendengar Rasulullah saw. bersabda: "Mimpi yang baik adalah berasal dari Allah, sedang mimpi yang buruk berasal dari setan, maka jika salah seorang diantara kalian bermimpi yang tidak disukainya, hendaklah meludah ke sebelah kirinya dan meminta perlindungan kepada Allah, niscaya yang sedemikian itu tidak membahayaknnya."

Terdapat 2 Term atau kata yang berarti mimpi pada matan hadis tersebut, yaitu

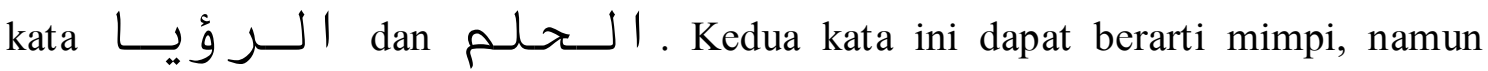

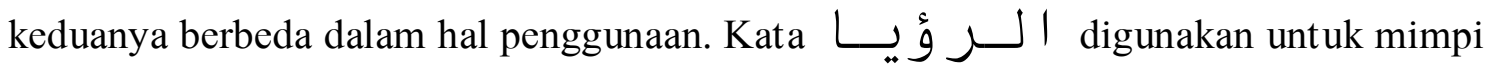
yang baik, benar dan sebagainya, hal ini dapat dilihat dari kata الله مـ yang

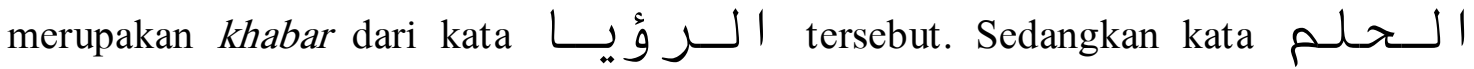
digunakan untuk mimpi yang tidak baik, kacau dan sebagainya, hal ini dapat dilihat

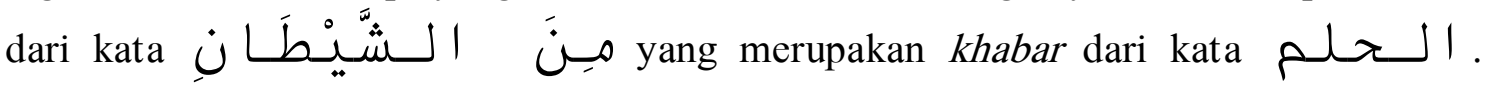
Untuk lebih jelasnya peneliti akan menjelaskan kedua kata tersebut secara rinci.

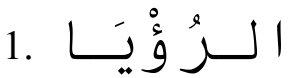

Kata ini merupakan bentuk Masdar (bentuk ketiga) yakni perubahan dari asal kata arti yaitu; melihat, berpendapat atau bermimpi. ${ }^{17}$ Menurut Ibn Fāris dalam kitabnya Mu'jam Maqāyis al-Lugah mengatakan bahwa kata ر J yang terdiri dari huruf $\jmath$,

\footnotetext{
${ }^{16}$ Al-Bukhārī, al-Jāmi‘ al-Ṣaḥịh, Juz IX, h. 35.

${ }^{17}$ Mahmud Yunus, Kamus Arab-Indonesia, (Jakarta: PT. Hidakarya Agung, 1411 H/ 1990 M), h. 136.
} 


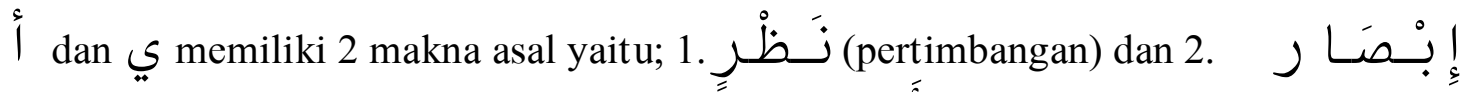

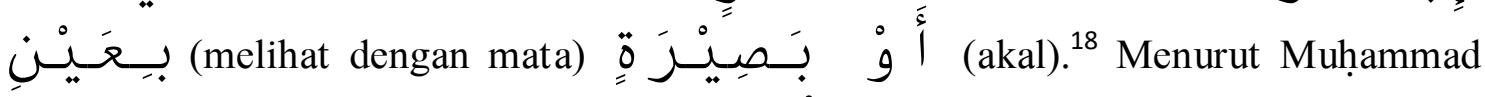
Ibn Makram menjelaskan bahwa kata dengan tanda baca ḍmmah

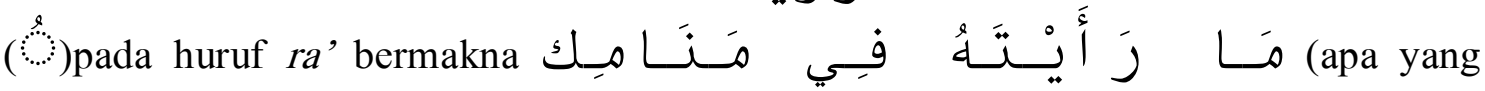

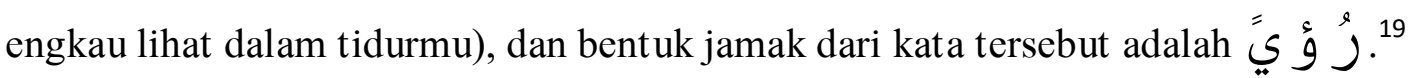

Berdasarkan paparan di atas, peniliti memahami bahwa penggunaan kata الـــ sebagai term mimpi berarti melihat sesuatu dalam tidur dengan panca indra.

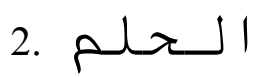

Kata ini merupakan bentuk masdar (bentuk ketiga) yakni perubahan dari asal kata $L^{\prime}$ dalam kitabnya Mújam Maqāyīs al-Lugah mengatakan bahwa kata حــ yang terdiri dari huruf $ح, J$ dan $\mathrm{J}$ memiliki 3 makna dasar yaitu; 1.

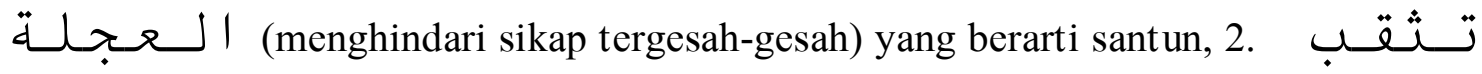

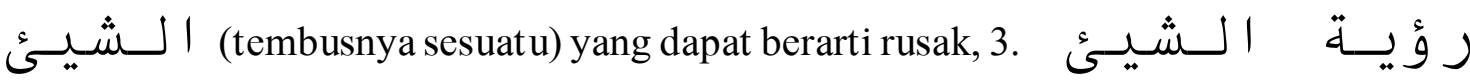
(terlihatnya sesuatu di dalam tidurnya) yang berarti bermimpi. ${ }^{21}$ Muhammad Ibn Makram dalam kitabnya Lisān al-'Arab menjelaskan

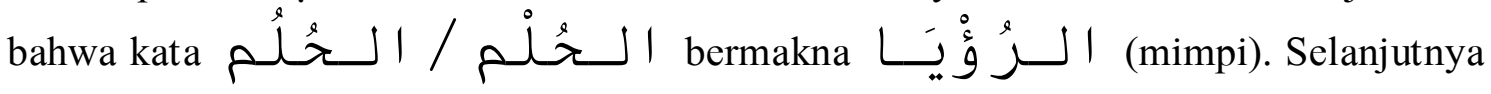
ia menjelaskan lebih lanjut bahwa الــا ؤيسا merupakan sebuah gaya bahasa dari apa yang dilihat oleh seseorang dalam tidurnya. ${ }^{22}$

Berdasarkan paparan di atas, peniliti memahami bahwa penggunaan kata الـحلـ menandakan bahwa seseorang yang bermimpi membutuhkan sikap santun, untuk memahami mimpinya, karena mimpi dapat menembus apapun.

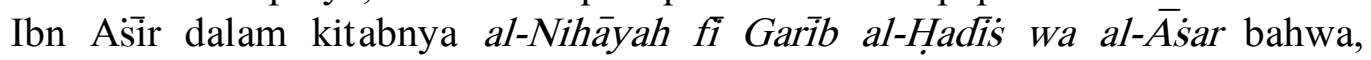
penggunaan kata lebih kepada apa yang dilihat seseorang dari sesuatu yang baik dan bagus dalam tidurnya, sementara kata lebih kepada apa

\footnotetext{
${ }^{18}$ Lihat Ibn Fāris, Ahmad Ibn Faris Ibn Zakariya Abu al-Husain, Mu‘jam Maqāyīs Al-Lugah, Juz II, (t.t.: Dār al-Fikr, 1399 H/ 1979 M), h. 472.

${ }^{19}$ Lihat Ibn Manẓūr, Muhammad Ibn Makram Ibn 'Ađi Abū al-Fạ̣l Jamāl al-Dīn, Lisān al-Arab, Juz XIV, (Cet. III; Bairūt: Dār al-Ṣādir, 1414 H ) h. 297

${ }^{20}$ Mahmud Yunus, Kamus Arab-Indonesia, h. 108.

${ }^{21}$ Lihat Ibn Fāris, Mu'jam Maqāyīs Al-Lugah, Juz II, h. 94

${ }^{22}$ Lihat Ibn Manzūr, Muhammad Ibn Makram, Lisān al-Arab, Juz XIV, h. 297
} 
yang dilihat dari sesuatu yang jelek dan buruk atau biasa juga dikatakan dengan istilah أ ضغنـا ث ا لأحهلام (mimpi yang kacau). ${ }^{23}$

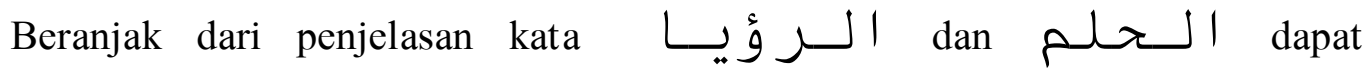
dirumuskan bahwa mimpi adalah sebuah gaya bahasa tentang sesuatu yang terlihat ketika seseorang sedang tertidur. Ketika seseorang sedang bermimpi maka seleruh anggota panca indranya akan terlibat dalam merekam gaya bahasa kejadian mimpi tersebut, sementara indra yang paling aktif ketika proses mimpi adalah mata. Selain

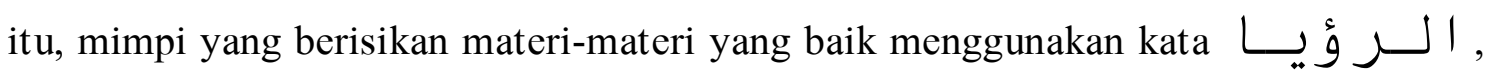
sedangkan untuk mimpi yang berisi materi buruk / kacau menggunakan kata atcil.

\section{METODOLOGI PENELITIAN}

Metode yang digunakan dalam pengumpulan hadis adalah metode takhrij yang meng-analisis (tahlili) kandungan hadis dengan menggunakan pendekatan Ilmu Hadis dan Ilmu Psikolog.

a. Pendekatan ilmu hadis

Dimensi kajian skripsi ini adalah hadis-hadis tentang tiga macam mimpi, sehingga langkah awal pada penelitian ini akan merujuk pada kitab sumber hadis terlebih dahulu. Selanjutnya, dalam melakukan interpretasi hadis, dapat dilakukan dengan menggunakan kitab ilmu hadis, seperti 'ilm rijall al-hadis, 'ilm al-jarh wa alta'di ${ }^{24}$, 'ilm ma'āni ${ }^{25}$ dan sebagainya.

b. Pendekatan psikologi

Psikologi adalah sebuah bidang ilmu pengetahuan dan ilmu terapan yang mempelajari mengenai perilaku dan fungsi mental manusia secara ilmiah. Tujuan dari pendekatan ini adalah untuk mengetahui kondisi manusia baik sebelum, pada saat bermimpi maupun setelah bermimpi.

\section{HASIL PENELITIAN DAN PEMBAHASAN}

Hadis Nabi saw. yang berbicara tentang sumber mimpi termaktub dalam beberapa kitab hadis.

Teks hadis yang menjadi fokus penelitian pada tulisan ini ialah hadis yang menyebutkan macam-macam mimpi kedalam tiga bagian, di mana hadis ini

\footnotetext{
${ }^{23}$ Lihat Ibn al-Asīir, Majd al-Dīn Abū al-Sa‘’̄alah al-Mubārak Ibn Muhammad Ibn Muhammad

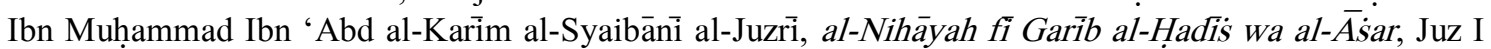
(Bairūt: al-Maktabah al-'Ilmiyyah, 1399 H/1979 M), h. 434. Lihat juga Abu Hilāl al-Hasan Ibn 'Abdullah Ibn Sahl Ibn Sa'ỉd Ibn Yahyā Ibn Mihrān al-'Askari, Mu'jam al-Furūq al-Lugawī, (Cet. I; t.t., Mu’assasah al-Nasyr al-Islāmī al-Tābi‘ah li Jam‘ah al-Mudarrisīn, 1412 H), h. 198.

${ }^{24}$ Ilmu yang membahas hal ihwal para periwayat dari segi diterima atau ditolak riwayat mereka. Lihat, Abd' al-Karim al-Khațīb, Ușūl al-Hadìs: 'Ulūmuh wa Muștalahuh (Bairūt: Dār al-Fikr, 1975 M), h. 266. Lihat, A. Syahraeni, Kritik Sanad dalam Perspektif Sejarah (Cet. I; Makassar: Alauddin Press, 2011 M), h. 99.

${ }^{25}$ Ilmu yang mempelajari tentang hal-ihwal kata Arab, sesuai dengan keadaannya, sehingga terjadi perbedaan pandangan tentang suatu kalimat karena perbedaan keadaan. Arifuddin Ahmad, Metodologi Pemahaman Hadis Kajian Ilmu Ma’ānì al-Hadis, h. 5.
} 
diriwayatkan oleh 7 dari 9 Imam (al-kutub al-tis 'ah), yaitu; Imām Ahmad, al-Bukhārì, Muslim, al-Turmużī, al-Dārimī, al-Nasā'ì dan Ibn Mājah yang diriwayatkan dari Abi Hurairah dan 'Awf ibn Mālik, adapun teks hadis tersebut ialah ;

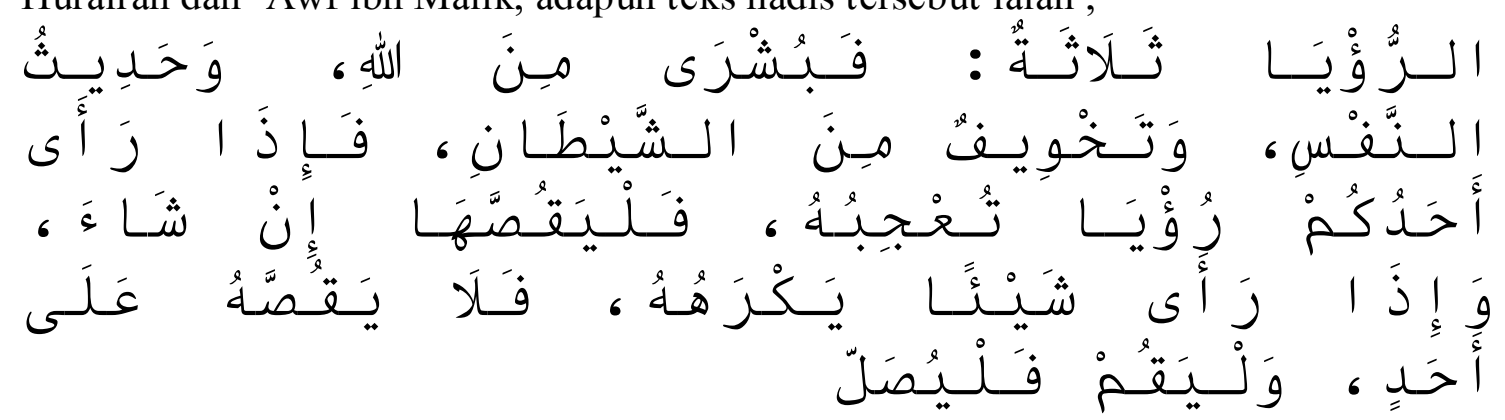

Artinya;

Mimpi itu ada tiga; berita baik dari Allah, panggilan jiwa dan ketakutan yang dihadirkan oleh setan. Maka jika salah seorang dari kalian bermimpi dengan sesuatu yang indah, jika dia mau hendaklah ia ceritkan, dan jika melihat sesuatu yang dibenci maka janganlah ia ceritakan, tetapi hendaklah ia bangun dan shalat."

Hadis di atas menggambarkan bahwa sumber datangnya mimpi ada 3 macam yaitu; 1. Busyrā min Allah, 2. Hadìis al-nafs dan 3. Takhwí min al-syaitān.

1. Busyrā min Allah (mimpi dari Allah)

Ibn al-Tayyib berkata bahwa segala sesuatu yang dilihat oleh manusia dalam tidurnya baik dari kebenaran ataupun kebatilan maka itu diciptakan oleh Allah. Jika yang terjadi adalah sebuah kebenaran maka itu diciptakan dengan hadirnya malaikat, dan jika yang terjadi adalah sebuah kebatilan maka itu diciptakan dengan hadirnya setan. $^{26}$

Abū Bākar Ibn al-'Arabì berkata bahwa mimpi merupakan perolehan-perolehan yang diciptakan oleh Allah dalam hati seorang hamba lewat malaikat atau setan baik berupa nama-nama, perumpaan, ataupun sesuatu yang membahayakan dirinya, lalu ia merasa khawatir pada waktu terjagannya maka sesungguhnya kejadian tersebut tidak akan menghasilkan apapun. Dan Jika Allah menciptakan perolehan tersebut dalam tidur seseorang lewat malaikat maka itu adalah wahyu yang disyairkan dan burhan yang dapat dipahami. ${ }^{27}$

Selanjutnya Ibn Hajar mengatakan bahwa "mimpi yang benar dibawa oleh malaikat, tidak tercampur hal-hal yang rancu dan angan-angan. Biasanya menjadi kenyataan yang menggembirakan, berbeda dengan bunga tidur. Oleh karena itu dinisbatkan kepada Allah sebagai penghormatan kepada-Nya". ${ }^{28}$

Berdasarkan paparan di atas, maka peneliti memahami bahwa pada dasarnya mimpi dari Allah adalah mimpi yang dibawa oleh malaikat sebagai perwakilan dari Allah untuk menyampaikan wahyu, ilham, petunjuk, dan berita alam gaib kepada

${ }^{26}$ Lihat Ibn Batṭāl, 'Ali Ibn Khalf Ibn 'Abd al-Malik Abū al-Ḥasan, Syarh Ṣaḥị̣ al-Bukhārī, Juz IX, (Cet. II; al-Riyāḍ-al-Su'ūdiyyah; Maktabah al-Rusyd, 1423 H/ 2003 M), h. 523.

${ }^{27}$ Lihat Abū al-Fạ̣l Zain al-Dīn 'Abd al-Rahīm Ibn al-Husain Ibn 'Abd al-Raḥman Ibn Abi Bakr Ibn Ibrāhīm al-'Irāqī, Țurh al-Taśrib fí Syarh al-Taqrīb, Juz VIII (t.t,: Al-Ṭab'ah al-Miṣriyyah alQadimah, t.th.), h. 206.

${ }^{28}$ Lihat Muhammad Ibn Fahd Ibn Ibrāhīm al-Wad‘ān, Dawābiṭ al-Ru’yā, (Cet. I; t.t,: Dār Kunūz Isybiliyyā li al-Nasyr wa al-Tawzī‘, 1428 H/ 2008 M), h. 21. 
seorang hamba melalui mimpi. Adapun penisbatan tersebut kepada Allah adalah sebagai penghormatan kepadanya.

Pada dasarnya kedatangan malaikat ke dalam tidur manusia tidak terlepas dari tugas yang diberikan kepadanya untuk menyampaikan kebenaran kepada manusia. Sebagaimana firmaan Allah dalam QS al-Hijr/15: 8 bahwa ;

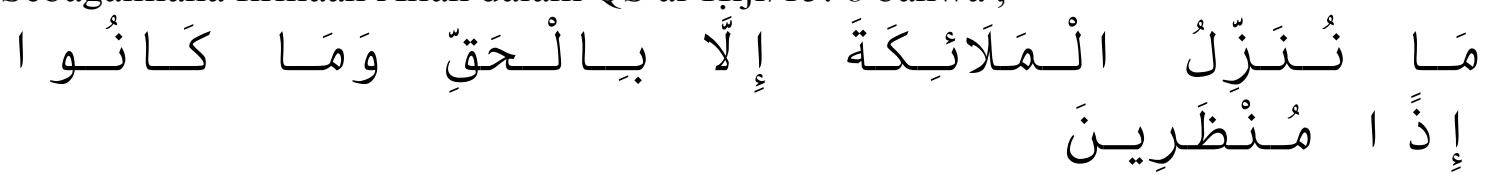

Terjemahnya ;

Tiadalah kami turunkan malaikat, melainkan dengan kebenaran (untuk membawa azab) dan mereka ketika itu tidak diberi penangguhan. ${ }^{29}$

Sebagaimana pula yang telah disabdakan oleh rasulullah saw. dalam sebuah hadis yang diriwayatkan oleh Imam al-Turmużi dalam kitab Sunan-nya dari 'Abdullah Ibn Mas'üd yang mengatakan ;

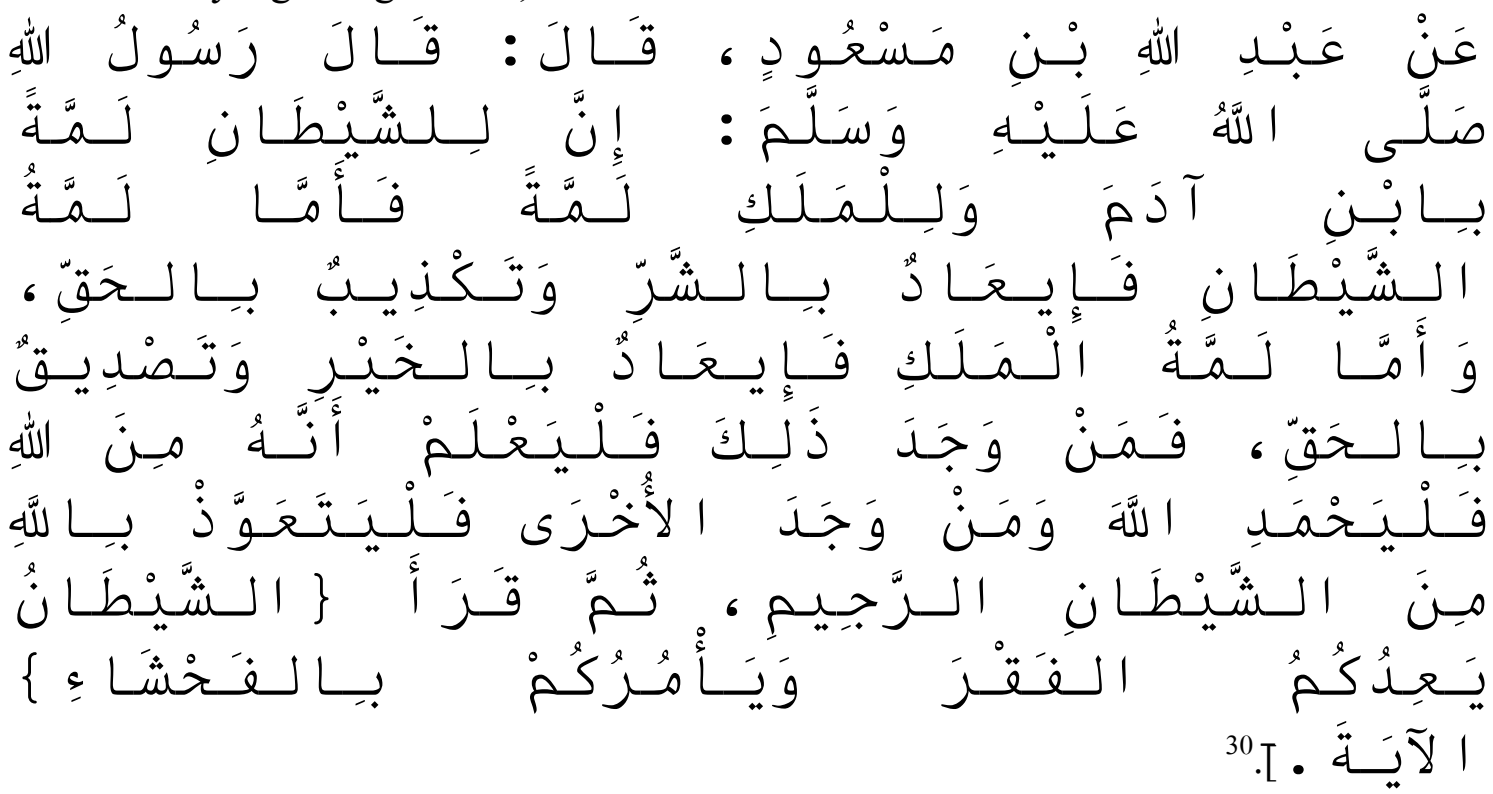

Artinya ;

Dari 'Abdullah Ibn Mas'ūd ia berkata; Rasulullah saw. bersabda: "Sesunguhnya setan memiliki bisikan was-was kepada anak cucu Adam, dan Malaikatpun memiliki bisikan, adapun bisikan setan selalu menjanjikan kejahatan dan mendustakan kebenaran, sedangkan bisikan para Malaikat selalu menjanjikan kebaikan dan membenarkan kebenaran, barangsiapa mendapatkan demikian (bisikan malaikat) maka ketahuilah, sesungguhnya itu dari Allah dan memujilah kepada Allah, namun barangsiapa mendapatkan yang lainnya (bisikan setan), maka berlindunglah kepada Allah dari setan yang terkutuk dan bacalah ayat: "setan menjanjikan (menakut-nakuti) kamu dengan kemiskinan dan menyuruh kamu berbuat kejahatan (kikir)." QS al Baqarah: 268.

\footnotetext{
${ }^{29}$ Departemen Agama RI, Al-Qur'an dan Terjemahnya, h. 262.

${ }^{30}$ Al-Turmużī, Abū 'Isa, Muhammad Ibn 'Isa Ibn Sawrah Ibn Mūsā al-Duḥ̣̂̄k, Sunan alTurmużī, Juz V, (Mesir: Syarikah Maktabah wa Maṭba‘ah Muṣṭafā al-Bābī al-Ḥalb, 1395 H/ 1975 M), h. 219.
} 
Hadis di atas menegaskan baik malaikat maupun setan memiliki bisikan terhadap manusia. Akan tetapi, bisikan dari malaikat akan membawa manusia kepada kebaikan dan kebenaran, sementara bisikan setan membawa manusia kepada kejahatan dan kebatilan.

Berdasarkan paparan di atas peneliti memahami bahwa mimpi yang berasal dari Allah adalah mimpi yang dibawa oleh malaikat sebagai perwakilan Allah dan berisikan mimpi baik dan benar sebagai berita yang menggembirakan bagi orang yang bermimpi.

2. Hadis al-nafs (omongan diri sendiri)

Sahl Ibn Rifá' mengatakan bahwa hadis al-nafs adalah sesuatu yang dilihat oleh manusia dalam tidurnya dari apa yang terjadi padanya dalam promblematika kehidupannya. Dari kekhawatiran yang mengalir tanpa maksud. ${ }^{31}$

Al-Bagawi berkata bahwa hadis al-nafs seperti orang yang berada dalam masalah atau kesialan lalu ia melihat dirinya dalam masalah tersebut, atau seperti orang yang mecintai melihat orang yang dicintainya. ${ }^{32}$

Al-Usāmah 'Abd al-Qādir berkata bahwa aḥāìis al-nafs seperti orang yang menaruh perhatian terhadap sesuatu pada saat terjaganya, lalu ia melihat hal tersebut di dalam tidurnya. Atau seperti orang yang berlatih berenang dan dia belum bisa setelah itu, maka ia melihat dalam tidurnya bahwa ia sedang berenang pada siang hari yang panas. $^{33}$

'Abd al-'Azīz Ibn Bāzi berkata bahwa ḥadis al-nafs bukan sesuatu yang baik ataupun buruk, dan tidak mengapa untuk menceritakannya. ${ }^{34}$

Berdasarkan paparan di atas, peneliti memahami bahwa hadis al-nafs adalah mimpi yang dilihat oleh seseorang berdasarkan keadaannya ketika menjelang tidur, jika pada saat menjelang tidurnya memikirkan sesuatu maka kemungkinan ia akan melihatnya ketika telah tertidur, atau dapat juga disebabkan oleh kekhawatiran, anganangan, harapan ataupun keinginan yang ada dalam hatinya (bisikan hati).

3. Al-Ru'yā min al-syaitān (mimpi dari setan)

Ibn Fāris menjelaskan bahwa setiap dari golongan jin, setan dan binatang yang membangkan serta durhaka adalah setan. ${ }^{35}$

Hasan al-Basri mengatakan bahwa jin adalah anak dari iblis dan manusia merupakan anak Adam a.s. di antara mereka ada yang beriman dan ada pula yang kafir, siapa di antara mereka yang beriman maka ia adalah kekasih Allah sementara di antara mereka yang kafir adalah setan. ${ }^{36}$

Berdasarkan penjelasan di atas maka peneliti memahami bahwa setan adalah sebuah sifat pembangkangan yang dilakukan oleh jin dan manusia terhadap ketetapan

\footnotetext{
${ }^{31}$ Lihat Sahl Ibn Rifa', al-Ru'yā 'Inda Ahl al-Sunnah wa al-Jamā'ah wa al-Mukhālifīn, h. 111.
}

${ }^{32}$ Lihat al-Bagawi, Syarh al-Sunnah, XII, (Cet. II; Damaskus-Bairut: al-Maktabah alIslāmiyyah, 1403 H/ 1983 M), h. 211.

${ }^{33}$ Lihat al-Usāmah 'Abd al-Qādir al-Rayyis, al-Ru'yā wa al-Aḥlām fī al-Nuṣūs al-Syar'iyyah, (Cet. I; t.t.: Dār al-Andalas, 1414 H/ 1993 M), h. 45

${ }^{34}$ Lihat Sahl Ibn Rifa', al-Ru'yā 'Inda Ahl al-Sunnah wa al-Jamā'ah wa al-Mukhālifïn, h. 112.

${ }^{35}$ Lihat Ibn Fāris, Mu’jam Maqāyīs Al-Lugah, Juz III,, h. 184.

${ }^{36}$ Lihat 'Ali Ibn Nāyif al-Syuhūd, al-Īmān bi al-Jin baina al-Haqüqah wa al-Tahwìl, (Cet. I; Malaysia: Dār al-Ma'mūr, 1432 H / 2010 M), h. 53. 
Allah. Akan tetapi yang dimaksud oleh hadis tentang tiga macam mimpi ini adalah mimpi yang berasal dari setan jin bukan setan dari golongan manusia.

Setan adalah musuh manusia yang tidak akan lelah untuk mengganggu manusia di setiap waktu dan tempat. Sebagaimana pernyataan setan yang di abadikan dalam QS al-A'rāf/07: 17 sebagai beriku ;

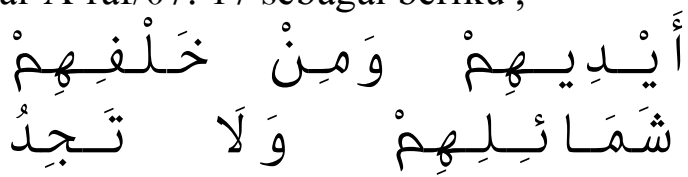

Terjemahnya ;

Kemudian pasti aku akan mendatangi mereka dari depan, belakang, kanan dan kiri mereka. Dan engkau tidak akan mendapati kebanyakan mereka bersyukur. ${ }^{37}$

Rasulullah saw. juga menjelaskan bahwa setan berjalan di dalam tubuh manusia melalui aliran darahnya, sebagaimana riwayat dari Anas Ibn Malik yang terdapat dalam kitab al-Musnad Șahịh bahwa;

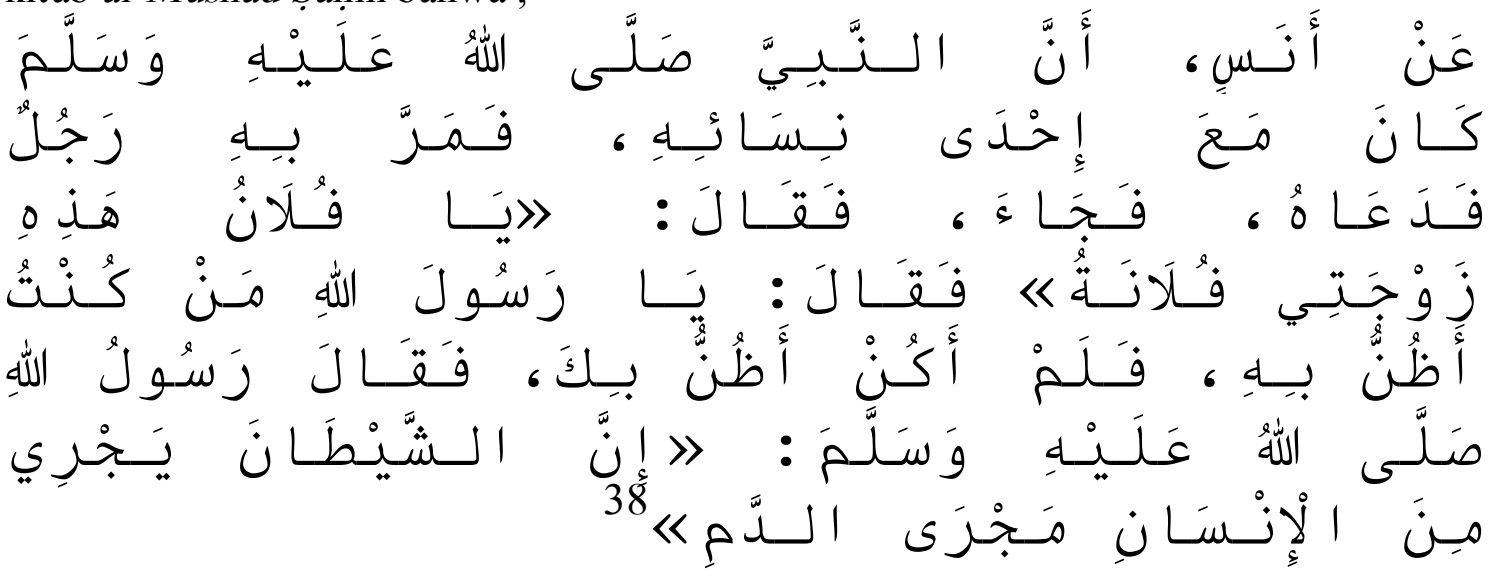

Artinya :

Dari Anas bahwa pada suatu ketika Nabi saw. sedang berdua dengan salah seorang isteri beliau. Kebetulan lewat ke dekat beliau seorang laki-laki. Orang itu dipanggil oleh Nabi saw. maka dia datang menemui beliau. Lalu Nabi shallallahu 'alaihi wasallam berkata kepadanya; 'Hai, Fulān! Ini isteriku, si Fulānah.' orang itu menjawab; 'Ya, Rasulullah! Aku tidak menduga-duga dengan Anda.' Beliau bersabda: 'Sesungguhnya setan berjalan dalam tubuh manusia melalui aliran darah.

Baik ayat maupun hadis Nabi saw. yang telah disebutkan, keduanya menunjukkan bahwa setan selalu mendekati manusia untuk melancarkan gangguannya dengan berbagai cara. Bahkan ketika tidurpun, setan akan mengganggu manusia melalui mimpi. Jika mereka tidak mampu mengganggu manusia di alam sadaranya, maka mereka akan mengganggu manusia di alam mimpinya karena sekuat apapun manusia, pasti akan sangat lemah ketika tertidur. Sekalipun ia merasa aman dari gangguan binatang dan manusia yang ada disekililingnya, tetapi tidak ada jaminan bahwa ia akan aman dari gangguan setan. Sebagaimana yang dikatakan oleh al-Hakīm bahwa "Setan selalu berusaha menguasai manusia dengan segala cara, karena dendam

\footnotetext{
${ }^{37}$ Departemen Agama RI, Al-Qur'an dan Terjemahnya, h. 152.

${ }^{38}$ Muslim Ibn al-Ḥajjāj, Abū al-Ḥasan al-Qusyairīi al-Naisabūrī, Al-Musnad al-Ṣahịh, Juz IV (Bairut: Dār Ihyāā al-Turās al-'Arabi, t.th.), h. 1712.
} 
dan kebenciannya. Berusaha mengusik ketenangan manusia, dalam tidurpun dia mengganggu dengan mimpi-mimpi aneh dan menyeramkan. Ini terjadi karena kesalahan dan kelalaian manusia itu sendiri." $" 39$

Allah swt. berfirman dalam QS al-Zukhruf/43: 36 bahwa ;

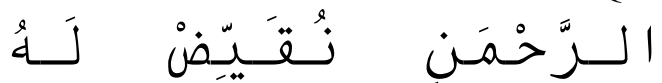

Terjemahnya ;

"Barang Siapa yang berpaling dari pengajaran Rabb yang Maha Pemurah (Alquran ). Kami biarkan setan (menyesatkan) dan menjadi teman karibnya."

Pada dasarnya, mimpi yang berasal dari setan tidak lepas dari izin Allah untuk mengganggu dan menyesatkan manusia sampai hari kiamat, hal ini di picu oleh penolakan iblis yang tidak mau sujud kepada nabi Adam a.s. dan kesombongannya dengan menganggap dirinya yang diciptakan dari api lebih baik daripada Nabi Adam a.s. yang diciptakan dari tanah. Maka oleh sebab itulah iblis dikeluarkan dari surga, kemudian iblis meminta penangguhan untuk menyesatkan manusia. Sebagaimana kisah perbincangan antara iblis dengan Allah yang terabadikan dalam QS al-A'rāf/7: 12-16 sebagai berikut ;

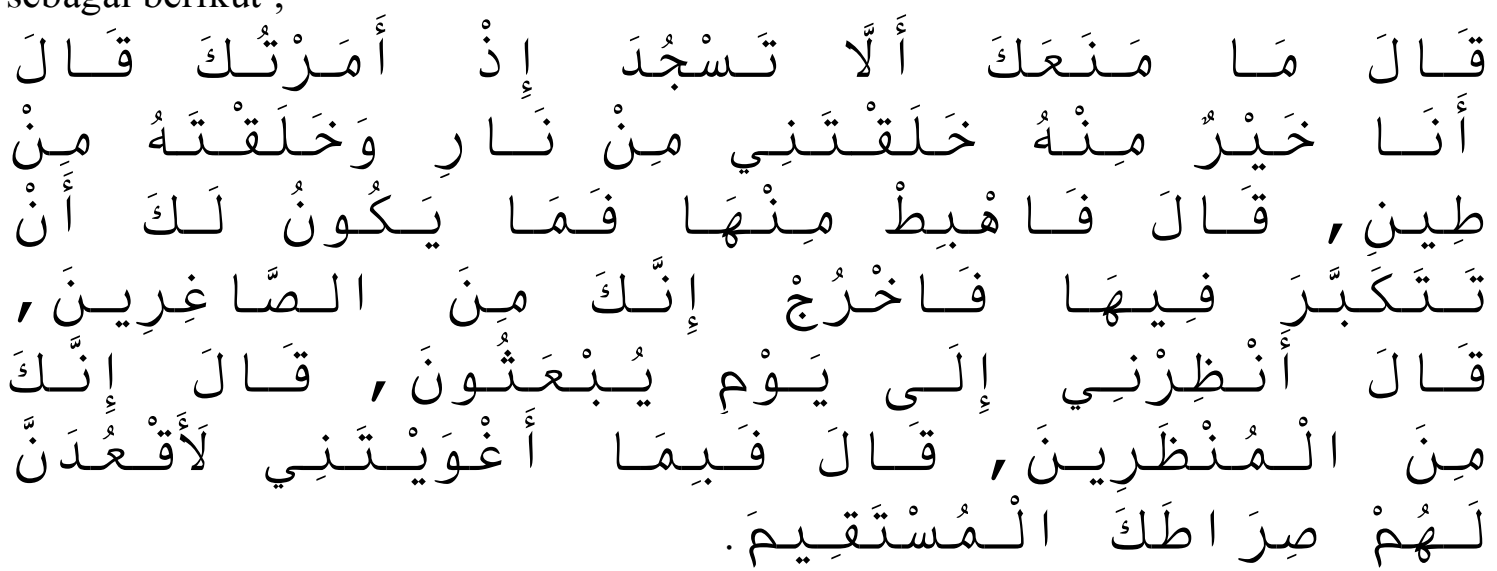

Terjemahnya ;

Allah swt. berfirman ; apakah yang menghalangimu untuk bersujud (kepada Adam) di waktu aku menyuruhmu? Iblis menjawab : aku lebih baik daripadanya, engkau ciptakan aku dari api sedang Dia Engkau ciptakan dari tanah. Allah berfirman; turunlah kamu dari surga itu, karena kamu tidak sepatutnya menyombongkan diri di dalamnya, keluarlah,! sesungguhnya kamu termasuk makhluk yang hina. Iblis menjawab; beri tangguhlah aku sampai mereka dibangkitkan. Allah berfirman; sesungguhnya kamu termasuk mereka yang diberi tangguh. Iblis menjawab ; karena engkau telah menghukum saya tersesat, saya akan benar-benar (menghalang-halangi) mereka dari jalan engkau yang lurus. ${ }^{41}$

Ayat di atas menunjukkan bahwa setan memiliki keleluasaan untuk terus menerus berupaya mengganggu dan membuat manusia tersesat dari jalan lurus yang

${ }^{39}$ Lihat Usāmah Muhammad al-'Awđ̣i, Ahkām Tafsìr al-Ru'ya wa al-Ahlām fì al-Qur'ān wa alSunnah al-Mutahharah, (Cet. I; t.t.: Maktabah al-Sunnah, 1410 H/ 1990 M), h. 14.

${ }^{40}$ Departemen Agama RI, Al-Qur'an dan Terjemahnya, h. 492.

${ }^{41}$ Departemen Agama RI, Al-Qur'an dan Terjemahnya, h. 152. 
telah Allah tunjukkan kepada manusia. Sekalipun ayat tersebut tidak menyebutkan secara spesifik bahwa setan akan mengganggu manusia melalui mimpi, tetapi pada ayat ke 17 pada QS al-A'rāf yang telah disebutkan sebelumnya menunjukkan bahwa melalui mimpi termasuk salah satu cara setan mengganggu manusia.

Ibrāhim Ibn Yahya dalam kitabnya Ta'bīr al-Ru'yā mengatakan bahwa "setan mampu menyerupai segala sesuatu, tetapi tidak mungkin baginya menyerupai bentuk Malaikat, Nabi, Matahari, Bulan, dan Bintang pada posisinya serta tidak pula dengan Awan beserta hujan, kitab Taurat, Injil, dan al-Qur'ān. Maka mereka (setan) tidak akan mampu merperdaya-mu dari hal-hal tersebut". ${ }^{42}$

Perkataan Ibrāhīm Ibn Yahya tersebut menunjukkan bahwa setan benar-benar memiliki banyak senjata dan kemampuan untuk mrngganggu manusia. Tetapi beriringan dengan kemampuan tersebut, setan tentunya masih memiliki keterbatasan dalam kemampuannya dan tidak mampu memperdaya manusia dengan hal-hal yang telah disebutkan oleh Ibrāhīm Ibn Yahya dalam kitabnya.

\section{PENUTUP}

Berdasarkan pembahasan di atas, maka dapat disimpulkan bahwa sumber datangnya mimpi ada tiga 3 , yaitu;

1. Mimpi yang berasal dari Allah melalui perantara malaikat yang telah ditugaskan oleh Allah. Mimpi tersebut memuat meteri yang bersifat baik, benar, menggembirakan serta merupakan petunjuk.

2. Mimpi yang berasal dari setan. Mimpi tersebut memuat materi yang bersifat tidak baik, buruk dan hanya berupa gangguan setan.

3. Mimpi yang berasal dari diri sendiri. Mimpi tersebut memuat materi yang berlandaskan kejadian yang terfikirkan ketika menjelang tidur, kemudian terlihat dalam keadaan tidur atau juga dapat berasal dari pengalaman/trauma.

Setelah meneliti hadis 3 macam mimpi ini, peneliti menyadari bahwa mimpi adalah sebuah peristiwa yang seringkali dialami oleh manusia, di mana mimpi itu merupakan salah satu cara Allah untuk memberikan kabar gembira / petunjuk kepada manusia yang diwakilkan oleh Malaiakat, namun melalui mimpi pula setan dapat mengganggu manusia dengan gambaran-gambaran yang kacau / buruk, sehingga manusia menjadi khawatir, bersedih bahkan sakit setelah melihatnya, selain itu terkadang pula mimpi itu hanyalah sekedar bunga tidur yang tidak memiliki makna ketika mimpi tersebut disebabkan oleh fikiran-fikiran, kekhawatiran ataupun keinginan, maupun khayalan di saat menjelang tidurnya, sehingga terbawa ke alam mimpi.

\footnotetext{
${ }^{42}$ Lihat Ibrāhīm Ibn Yahyā Ibn Ganām al-Mu'abbir, Ta 'bïr al-Ru’yā, (t.t.: Maktabah al-Jāmi'ah al-Urdūniyyah, t.th.), h. 9.
} 


\section{DAFTAR PUSTAKA}

Abū 'Abdillah al-Ju'fî, al-Bukhārì Muhammad Ibn Ismā'îl. Al-Jāmi' al-Ṣaḥịh, Juz 7 dan 9. Cet. I; t.t: Dār Ṭūq al-Najāh, 1422 H.

Abū al-Ḥasan al-Asy'arì, 'Ali Ibn Ismā'îl Ibn Ishāa Ibn Sālim Ibn Ismā‘ìl Ibn 'Abdullah. Maqālät al-Islāmiyyīn wa Ikhtilāf al-Musallin. Cet. II; Madinah: Dār Farāniz Syitāyiz, 1400 H/1980 M.

Abu al-Husain, Ahmad Ibn Faris Ibn Zakariya. Mu'jam Maqāyis al-Lugah. Juz 2, 3. t.t., Dār al-Fikr, 1399 H/ 1979 M.

Abū Muhammad, al-Bagawi al-Husain Ibn Mas'ūd Ibn Muhammad Ibn al-Firā'ì alSyāfi'i. Syarh al-Sunnah. 12. Cet. II; Damaskus-Bairut: al-Maktabah alIslāmiyyah, $1403 \mathrm{H} / 1983 \mathrm{M}$.

------. Ma'ālim al-Tanzīl fí al-Tafsìr al-Qur'ān. Juz 4. Cet. IV; t.t.: Dār Tayyibah li alNasy wa al-Tawzi`‘ 1417 H / 1997 M.

al-Āmili, Abū Ja'far al-Tabari, Muhammad’ Ibn Jarīr Ibn Yazīd Ibn Kasīir Ibn Gālib. Jāmi` al-Bayān fì Ta'wīl al-Qur'ān. Juz 15. Cet. I; t.t: Mu'assasah al-Risālah, $1420 \mathrm{H} / 2000 \mathrm{M}$.

al-'Askarì, Abu Hilāl al-Hasan Ibn 'Abdullah Ibn Sahl Ibn Sa‘ìd Ibn Yahyā Ibn Mihrān. Mu'jam al-Furūq al-Lugawi. Cet. I; t.t.: Mu'assasah al-Nasyr al-Islāmì alTābi'ah li Jam‘ah al-Mudarrisin, 1412 H.

al-'Awḍ̛i, Usāmah Muhammad. Aḥkām Tafsìr al-Ru'ya wa al-Ahlām fī al-Qur'ān wa al-Sunnah al-Mutahharah. Cet. I; t.t.: Maktabah al-Sunnah, 1410 H/ 1990 M.

al-Dārimī, Abū Muhammad bin 'Abdillah bin 'Abd al-Raḥman bin al-Faḍl bin Bahrām bin 'Abd al-Ṣamad. Musnad al-Därimī. Juz 2. Cet, I; Al-Mamlakah al'Arabiyyah al-Su'ūdiyyah; Dār al-Muganni li al-Nasyr wa al-Tauzī', 1412 H/2000 M. 
Departemen Agama RI. Al-Qur'an dan Terjemahnya. Cet., I, PT Tiga Serangkai Pustaka Mandiri, $1430 \mathrm{H} / 2009 \mathrm{M}$.

al-Duhḥ̄āk, al-Turmużi Abū 'Isa Muhammad Ibn 'Isa Ibn Sawrah Ibn Mūsā. Sunan alTurmużī. Juz 5. Mesir: Syarikah Maktabah wa Maṭba'ah Muṣtafāa al-Bābì alHạalb, 1395 H/ 1975 M.

Ibn Batṭāl, Abū al-Ḥasan 'Ali Ibn Khalf Ibn 'Abd al-Malik. Syarḥ Sạhịh al-Bukhārì. Juz 9. Cet. II; al-Riyāḍ-al-Su'ūdiyyah: Maktabah al-Rusyd, 1423 H/ 2003 M.

Ibn Khaldūn, 'Abd al-Raḥman Ibn Muhammaad Ibn Muḥammad. Dỉwān al-Mubtada' wa al-Khabr fì Tärīkh al-'Arab wa al-Barbar. Juz I. Cet. II; Bairūt: Dār al-Fikr, $1408 \mathrm{H} / 1988 \mathrm{M}$.

al-'Irāqì, Abū al-Faḍl Zain al-Dīn 'Abd al-Rahīm Ibn al-Ḥusain Ibn 'Abd al-Raḥman Ibn Abī Bakr Ibn Ibrāhim. Turh al-Taśrīb fî Syarh al-Taqrīb. Juz 8. t.t.: AlTab'ah al-Mișriyyah al-Qadimah, t.th.

Jamāl al-Dīn, Ibn Manẓūr Muhammad Ibn Makram Ibn 'Ali Abū al-Faḍl. Lisān alArab. Juz 14. Cet. III; Bairūt: Dār al-Ṣādir, 1414 H.

al-Juzrīi, Ibn al-As̄ìr, Majd al-Dīn Abū al-Sa‘’̄adah al-Mubārak Ibn Muhammad Ibn Muhammad Ibn Muhammad Ibn 'Abd al-Karìm al-Syaibānì. Al-Nihāyah fí

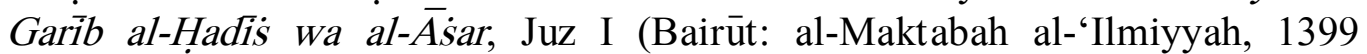
H/1979 M), h. 434. Lihat juga

al-Khațīb, Abd' al-Karim. Ușūl al-Hadis̀: 'Ulūmuh wa Muștalahuh. Bairūt: Dār al-Fikr, $1975 \mathrm{M}$.

al-Mu'abbir, Ibrāhīm Ibn Yaḥyā Ibn Ganām. Ta 'bìr al-Ru'yā. t.t.: Maktabah al-Jāmi'ah al-Urdūniyyah, t.th.

al-Naisabūrì, Muslim Ibn al-Ḥajjāj, Abū al-Ḥasan al-Qusyairì. Al-Musnad al-Saḥịh. Juz 4. Bairūt: Dār Ihyā al-Turās al-'Arabì, t.th.

al-Rayyis, al-Usāmah 'Abd al-Qādir. Al-Ru’yā wa al-Aḥlām fī al-Nuṣụ̄ al-Syar'iyyah. Cet. I; t.t.: Dār al-Andalas, 1414 H/ 1993 M..

Shihab, M. Quraish. Dia Dimana-Mana. Cet. IV; t.t.: Lentera Hati, 1427 H/2006 M.

Syahraeni, A. Kritik Sanad dalam Perspektif Sejarah. Cet. I; Makassar: Alauddin Press, $2011 \mathrm{M}$.

Syāms al-Dīn, Ibn Qayyim al-Jauzī, Muhammad Ibn Abī Bakr Ibn Ayyūb Ibn Sa'ad. I'lām al-Muwaqqi în an Rabbi al-'Ālaminn. Juz 1. Cet. I; Bairūt: Dār al-Kutub al-'Ilmiyyah, $1411 \mathrm{H} / 1991 \mathrm{M}$.

al-Syuhūū, 'Ali Ibn Nāyif. Al-İmān bi al-Jin baina al-Haqīqah wa al-Tahwīl. Cet. I; Malaysia: Dār al-Ma'mūr, 1432 H / 2010 M.

al-'Utaibì, Sahl Ibn Rifā' Ibn Suhail. Al-Ru'yā 'Inda Ahl al-Sunnah wa al-Jamā'ah wa al-Mukhālifîn. Cet. I; t.t.: Dār Kunūz Isybiliyyah li al-Nasyr wa al-Tauzī‘, 1430 
H/2009 M.

al-Wad‘ān, Muḥammad Ibn Fahd Ibn Ibrāhīm. Dawābit al-Ru’yā. Cet. I; t.t: Dār Kunūz Isybiliyyā li al-Nasyr wa al-Tawzi'‘, 1428 H/ 2008 M.

Yunus, Mahmud. Kamus Arab-Indonesi. Jakarta: PT. Hidakarya Agung, 1411 H/ 1990 M. 